\title{
Corporate Brand Value Shifting from Identity to Innovation Capability: from Coca-Cola to Apple
}

\author{
Ray R. Gehani*
}

\begin{abstract}
Corporate brand value, a key corporate asset, has traditionally relied on stakeholder interactions, heritage, and corporate identity. In dynamic fast clock-speed industries (information technology and consumer electronics), we note that brand values change dramatically within a few years based on their innovativeness. Using grounded theory approach and multi-case study method we examine how Apple, Samsung, Toyota, and Coca-Cola sustained their most valuable global brands while Kodak and General Motors eroded the same. Certain key dynamic innovative capabilities are identified as best practices. We conclude with implications for managers and future researchers, along with some limitations.
\end{abstract}

keywords: Corporate brand value; dynamic innovative capabilities; competitive advantage; brand equity; hyper-competitive industries

Submitted: April 10th 2016 / Approved: September 11th 2016

\section{Corporate brand value}

Due to the intense proliferation of established and emerging brand offerings, the global markets are becoming highly crowded and turbulently dynamic with time-based competition (Gehani, 1995). Yet, some brands, such as Apple and Coca-Cola are able to stand out and are often preferred by customers over others. Brand value as a corporate asset is one of the primary measures of competitive advantage of an enterprise that is useful to gain customers' brand preference over rivals (Aaker, 2012). Enterprises also increase their brand relevance and gain brand leadership in their product categories to enact entry barriers for their rivals and new entrants (Porter \& Happelmann, 2014).

For example, Google, Microsoft, Intel, and Samsung dominate their respective categories. With their innovations they have altered the way we live our lives in the $21^{\text {st }}$ century. These corporate brands, therefore, lead the world's most valuable global brands. On the other hand, the 100-year old iconic Coca-Cola brand led the world's most valuable brands for more than a decade until 2012 (Interbrand, 2015). Thus, how does a corporate brand become a global leader in brand value?

\section{Corporate brand and identity}

In the past, a corporate brand was primarily managed by building a distinctive image. This gradually turned into a corporate identity (Aaker, 1991; 2004). This image was strengthened by clarifying brand relevance, which defined its product scope and the brand boundaries of its overall business. Thus, a corporate brand represented the enterprise with its unique characteristics and identity, such as credibility.

In 1960, the American Marketing Association defined a brand as a trademark, a distinctive name of a product or manufacturer, sign, symbol, design or any combinations used to identify the goods and services of a seller to differentiate its offerings from those of its competitors. Corporate brands can block the trespass of a rival with their distinctiveness.

The different identities and characters of brands are built on their heritage. Budweiser and Anheuser-Busch brands promote their rich heritage with symbols such as the Clydesdales horse-drawn carriages. But, at the same time, they want to reach out to the young and more intensive users of Budweiser and Bud Light beers. So their brands introduce campaigns against drunk driving, and use humorous advertisements about Lizards, Was-Up, and quaking toads. This helps them balance their old heritage with a contemporary touch.

Relying primarily on the nostalgia of heritage or character may have worked for many years in slow moving commodity related industries. But intensity of rivalry and rules of market competition tend to change much more rapidly in dynamic markets for high-tech industries or global geographical domains (Porter \& Heppelmann, 2014). In dynamic markets, new brands may rise to the top in 5-10 years, or the old established brands may crash and disappear in the same period (Gehani, 1995). Are corporate brands shifting from representing their heritage and identity to representing their innovativeness?

\section{Brands and market dynamics}

In fast moving industries or global markets, such as for tablet computers and smart-phones, new entrants can disrupt and dislodge well established brands in short periods of time with their innovations. Building a global corporate brand usually takes enormous time, resources, and efforts over multiple years (if not decades). But with globalization, social media, and disruptive innovations (Christensen, 1997; Gehani, 1998) some well established brands, such as Kodak, have lost billions of dollars of their corporate brand value in just a few years.

*University of Akron. Ohio, USA

E-mail: rgehani@uakron.edu 
Eastman Kodak was an iconic corporate brand for over a century since 1880s. It was one of the 30 blue chip companies in Dow Jones Index. Kodak ranked \#30 in the world's most valuable global brands until 2002, with a brand value of US\$ 9.7 Billion (www.Interbrand.com). But within a decade, the memorable 'Kodak Moment' became a nightmare for hundreds of thousands of stakeholders, including employees, suppliers, and stockholders when Kodak declared Chapter 11 bankruptcy in January 2012 (Daneman, 2014). This brand erosion took place because Kodak did not keep up with its innovativeness in digital imaging products, even though millions of customers around the world could easily recall the Kodak's brand with the iconic 'Yellow Box.'

Same is the case with the legendary auto leader General Motors (GM), with age-old household brands like Chevrolet, Buick, and their new monster gas-guzzler Hummer. GM declared Chapter 11 bankruptcy and requested government bailout in June 2009 (Isidore, 2009).

Aakers (2004) proposed that corporate brands, when they are struggling (such as Sony, Kodak or General Motors), they must go back to the roots of their heritages. Reflect how they had become so successful in the first place - against all the odds and hardships they faced. Hewlett-Packard started in a garage - with nothing but the intellectual capital and dreams of two young founders and \$550. Honda tinkered engines during the war-time shortages in the 1940s. and the post-war starvation in Japan in the 1950s. Corporations must not forget their founder-innovators' adventures. They must reflect and re-interpret their past innovations in today's global and more dynamic contexts (Gehani, 1995).

In this paper we explore how closely corporate brands have become related to the innovativeness of their owners. At the surface, brand recognition may seem to depend significantly on the eye-catching 30 -second U.S. super-bowl or Olympics sponsorships. But over the years, the corporate brand value of an enterprise reflects the innovativeness of the owner and the functionality of its products. After all, the brand is a signal for the source of different goods and services. And, therefore, customer-delighting goods and services, which go beyond marginal customer satisfaction, are rewarded with brand loyalty (Gehani, 1998). Enterprises, therefore, must offer innovative and exciting goods and services that match the value of their brands (Gehani, 2013).

Global corporate brands, therefore, must impart their aspirational values by making statements not only about their quality, reliability, and prices, but also communicate images of the new desirables. Such as their innovativeness and sustainability (as Coca Cola and Apple often do).

\section{Research Method}

The focus of this study is to explore the role of dynamic innovative capabilities of enterprises in determining their corporate brand values. Based on such examination, we will recommend some common best practices about dynamic capabilities that leading global enterprises develop and employ.
This research study uses a hybrid research design combining a grounded theory approach (Glaser and Strauss, 1967) with longitudinal evolutionary and cross-sectional analyses based on case studies and closely examined empirical evidence (Yin, 1994). The grounded theory approach and case studies are better suited to help explore innovative new propositions, and to elaborate "how" and "why" certain postulated relationships operate. On the other hand, the traditional comparative statistical research methods are effective to test "if" certain hypothesized propositions are supported by selected qualitative or quantitative data.

We will also use the guidance provided by Perrow (1967) recommending that researchers should try to control for the significant moderating effect of organizational technology in different industries. Therefore, our discussions and interpretations are limited to intra-case and inter-case analyses of intra-industry innovation capabilities and organizational performances measured by their corporate brand values (Eisenhardt and Graebner, 2007). No inferences will be conjectured or claimed regarding any inter-industry cross-sectional comparisons. Our level of inquiry is the firm or organization level. This permits using some of the publicly reported and audited financial information. Such secondary information will facilitate the use of grounded theory approach to develop new insights into our postulated relationship between corporate brand value and dynamic innovative capabilities of enterprises.

\section{Literature review: from identity to innovation based branding}

\section{Brand identity and stakeholder interactions}

Traditionally, a corporate brand value was considered to be driven from the interactions an enterprise has with its diverse stakeholders (Abratt \& Kleyn, 2012). For example, many potential employees prefer employment with Apple over Microsoft. Millions of customers contribute to Toyota's brand equity by buying hybrid Prius over Ford Taurus. Many investors are willing to pay much higher stock price-to-earnings ratio for Google than for its predecessor and rival Yahoo (Abratt \& Kleyn, 2012; Melewar et al., 2012).

Therefore, Balmer (2012) and others have noted that strategic branding must be constantly communicated with stakeholders inside an organization, and outside in its market environment. Such corporate brand development plays a significant role in business to consumer interactions as well as in business to business transactions.

\section{Brand value and erosion}

As a result of such efforts, over some years, a corporate brand value can account for a significantly large share of the overall market capitalization value of a global enterprise (see Table-1). Whereas this share of brand value becomes very noteworthy at the time of a merger or an acquisition, the brand value also plays a key role in the day to day survival and competitive growth of a global enterprise. 
Table-1: Corporate Brand Values of Global Leaders (2000-2015)

\begin{tabular}{ccccc}
\hline YEAR & COCA-COLA & APPLE & SAMSUNG & TOYOTA \\
\hline \$ Billion & \$ Billion $\$$ Billion & \$ Billion & & \\
\hline 2015 & 78.4 & 170.3 & 45.3 & 49.1 \\
& & & & \\
2014 & 81.6 & 118.9 & 45.5 & 42.4 \\
2012 & 77.8 & 76.6 & 32.9 & 30.3 \\
2010 & 70.5 & 21.1 & 19.5 & 26.2 \\
2008 & 66.7 & 13.7 & 17.7 & 34.1 \\
& & & & \\
2006 & 67.0 & 9.1 & 16.2 & 27.9 \\
2004 & 67.4 & 6.9 & 12.6 & 22.7 \\
2002 & 69.6 & 5.3 & 8.3 & 19.5 \\
2000 & 72.5 & 6.6 & 5.2 & 18.8 \\
\hline
\end{tabular}

Source: Adapted from various reports of BusinessWeek and Interbrand

Considering the strategic significance of corporate brand value, and its impact on an enterprise and its masses of stakeholders, it can be no more just managed functionally at the marketing department level. In fact, a growing distinction is being made between managing a product brand in the marketing department, and governing a corporate brand by the firm's strategic leadership. The focus in this paper is on the latter. (Balmer, 2012; Melewar, Gotsi \& Andriopoulos, 2012).

\section{Shifting tectonic terrain of innovation}

The landscape for innovation has been shifting dramatically since the dawn of the $21^{\text {st }}$ Century, and the ubiquitous growth and proliferation of first the Internet and then the social media such as Facebook, Twitter, and many more (Gehani, 1995). Innovative and inter-connected products are transforming competition as well as the value-chains of corporations (Porter \& Heppelmann 2014). This shifts product development from mostly mechanical engineering to systems development. In the past, the corporations with deep pockets and high investments in inventions and research \& development (R\&D) were considered more innovative. Think General Electric (with Thomas Edison's legacy), AT\&T (including Bell Labs), and DuPont (with Pioneering R\&D Lab). But, the tsunami of computer-enabled digital technologies, starting in garages and college dormitories, altered all that. The Millennial "Me-centric" customers quickly switched from iconic long-established brands to newly emerging user-centric brands. Move over Levi's and Limited, welcome Abercrombie \& Fitch and Zara. Design and user experiences have become the new imperatives for market success. Apple's late-founder CEO Steve Jobs was a major catalyst in this transformational movement from R\&D driven innovation to design-driven innovation (Isaacson, 2011).

Where does the value of a corporate brand come from? How are these brand values determined?

\section{Defining terms and boundaries}

As mentioned before, the conventional practice of brand management was focused on shareholder analysis and identity building (Aaker,
1991; Kapferer, 1997; Keller, 1998). But over the past few decades, many researchers from different disciplines have been using certain common terms quite inconsistently. For example, there still seems no consensus on a shared definition of the terms brand value or brand equity, except that it adds value to the overall enterprise.

In accounting literature, brand equity is the value of a brand as a separable asset, as included on a balance sheet, or when sold (Kapferer, 1997). On the other hand, the market researchers consider brand as the strength of consumers' attachment to a brand, and its associated beliefs (Keller, 1998). When marketers use brand equity, they refer to brand strength. Some researchers, therefore, have started differentiating these different meanings by using a new term: 'consumer brand equity' (Wood, 2000).

Ambler and Styles (1996) consider brand equity as a dormant profit to be realized in future. Such expectations based definition is also supported by Srivastava and Shocker (1991), who consider brand as 'all accumulated attitudes and behavior patterns in the extended minds of consumers, distribution channels, and influence agents, which affect long term cash flows and future profits.'

In view of the various inevitable challenges for estimating brand valuation, in this paper we will use the brand values estimated consistently by the same leading brand management agency: Interbrand in collaboration with BusinessWeek. The Interbrand valuation is based on three key components: financial analysis of profit performance, brand's role in purchase decisions (relative to price, features, convenience etc.), and brand's competitive strength for creating future loyalty. Interbrand uses expert's panels as well as extensive data from Thomason Reuters's company annual reports, Datamonitor consumer goods data and Twitter's social media signal. We will, however, limit our discussions and comparisons within an industry, and will not imply any deeper significance to the value of a corporate brand.

In the next section, as stated before, we will use grounded theory approach to analyze the longitudinal development of four iconic global brands in the top-10 highest brand values in the world. They are the leaders in their global industries. We have chosen the period from the dawn of the New Millennium in 2000 to 2015.

\section{Case study 1: Corporate brand value of Coca-cola}

Coca Cola has sustained its brand leadership for more than a century with its Spencerian scripted logo and distinctive waist-band bottle shape (Acevedo, 2008: 2). Until 2012, for more than a decade, Coca Cola was the world's most valuable Best Global Brand that steadily rose from \$72.5 Billion in 2000 to $\$ 77.8$ Billion in 2012 (See Table-1). During this period, the corporate brand value of Coke consistently scored higher than brand values of technology giants such as IBM, Microsoft, Google, and even Apple.

Long before the arrival of social media, Coca-Cola built a lasting brand based on nurturing the social moments of sharing their drinks with family and friends. Interestingly, Coca-Cola still had $73.2 \mathrm{Mi}-$ llion Facebook fan pages, far ahead of 15.1 Million for Google and 
9.8 Million for Apple (Elliott, 2013). In 2015, Coca-Cola ranked third most valuable Global Brand in the world, with an estimated corporate brand value of \$78.4 Billion (Interbrand, 2015). Only Apple and Google exceeded Coke's brand value, as they innovated new digital ways to stay connected with their customers.

What efforts and practices have contributed to Coca-Cola's phenomenally high corporate brand value?

\section{Customer connectivity}

In 1886, Coca Cola started by promoting a medicinal drink to cure headaches. Some suspect that one of its secret ingredients may have been an intoxicant from the cocaine plant family. The company achieved exponential growth for sales of concentrate syrup by giving away licensing bottling rights to others for a low price.

In 1984, with fast creeping market threat from sweeter Pepsi Cola brand, Coca-Cola chair Robert Woodruff approved his successor CEO Roberto Goizuetta to launch the "New Coke" brand - based on their extensive 'blind' market research. The loyal customers of the original coca-cola were outraged and reacted strongly against the withdrawal of their favorite drink. The old drink was quickly brought back and re-branded as the Classic Coke. At Coke, customers always come first.

Coca Cola's brand strength was built on the company's primary empathy for their customers' delightful experience. Their ad campaigns such as "The Real Thing," and "Enjoy" became iconic components of American culture. In 1923, the company promoted "Pause and Refresh Yourself." This was changed to "The Pause That Refreshes" in 1929, when the Great Depression was kicking in. Then came "Things Better with Coke" in 1963, "It's the Real Thing" in 1969, and on and on, until "Open Happiness" in 2009. Coke's brands and slogans symbolize America all over the world.

\section{Social Responsibility and Stakeholder Interactions}

Coke has often strengthened its corporate brand by promoting the company's corporate social and environmental responsibility mission. CEO Robert Woodruff supported civil rights, and donated large sums of money to Emory University in Atlanta where Coca-Cola has global headquarters. Even after his retirement, the Woodruff Foundation has been a major philanthropic institution supporting arts, education, and medical research.

Coke's new corporate priorities are "Women, Water, and Well-being" for the "Me, We, World." 'Me' is for enhancing personal well-being. 'We' is for community development. And the 'World' is for protecting the environment.

In late 2010, Coca-Cola launched a 5by20 initiative to empower 5 million women around the world by 2020 (Overbolt, 2012). CocaCola noted that whereas almost $50 \%$ of its workforce is women, very few of the distributors are women. The company reached out to women entrepreneurs in Brazil and enabled them to acquire truck licenses and digital computing technology to become the company's first-generation distributors. In poor countries, Coca-Cola provided solar-powered coolers to women shopkeepers to help them use solarpowered lanterns ad keep their shops open for longer hours.

In India, Coca-Cola has a very popular mango-based drink Mazza with $80 \%$ market share (Christensen, 2013). The demand was growing so fast that Coca-Cola was unable to keep up with the growing demand. The company worked with 30,000 small mango growers so that they could grow 2-3 times more mangoes than they could grew before. This was win-win-win as it helped the company get more supplies, the farmer earned more money, and the country boosted its gross-domestic-product (GDP)

The company has also adopted water stewardship in a big way. Water is a critical raw material for Coke's business. This is also in line with the United Nations' millennial goal of providing basic access to water and sanitation to the poor millions of the world. The company refers to it as connected capitalism (Christensen, 2013).

\section{Environmental responsibility}

Coca Cola is also focusing attention on re-designing and innovating its packaging for sustainability. In the 1960s, the Coke branded cans and bottles littered everywhere. The company mobilized its valueadding resources such as $\mathrm{R} \& \mathrm{D}$, engineering, and manufacturing, all collaborating together, to re-design a more sustainable next-generation delivery packaging. Designers played a key role in introducing new thinking.

First was the use of recycled poly-ethylene-terephthalate (PET). The manufacturing process was altered to incorporate some recycled PET (Christensen, 2013). More recently, more dramatic innovations such as bio-degradable bottles have been launched to strengthen the corporate brand value.

\section{Case study 2: Corporate brand value of Apple}

Even when Apple had a minor share of the overall personal computer market, it held a relatively high ranking among the world's most valuable Top 100 corporate global brands. This was because of its widely acknowledged design elegance, technological innovations, and delightful user experiences. Apple developed high brand relevance, and a leadership in its product sub-category for design professionals (Wright, Millman and Martin, 2007).

In 2001, Microsoft with a brand value of \$65.1 Billion, and IBM with a brand value of $\$ 52.8$ Billion were more than 10 times more valuable than Apple's brand value of mere \$5.5 Billion. Google had yet to enter the Top 100 Global Brands. In 2008, Apple's brand was valued at $\$ 13.7$ Billion, ranking at \#24 (see Table-1). Then it went to \#17 in 2010 with a brand value of $\$ 21.1$ Billion, and in 2012 it landed on \#2 position at $\$ 76.6$ Billion with an unimaginable $129 \%$ annual increase in brand value. With time-based competition, Apple overtook past Microsoft's brand value of $\$ 57.9$ Billion and even $\$ 72.2$ Billion brand value of IBM and Google’s \$69.7 Billion brand value (Gehani, 1995).

In 2015, Apple's corporate brand sat at the pinnacle of the world's most valuable global brands. It was valued at $\$ 170.3$ Billion: $\$ 50 \mathrm{Bi}-$ llion higher than Google’s \$120.3 Billion, and over \$100 Billion more 
than Microsoft's \$67.7 Billion and IBM’s \$65.1 Billion. Apple’s brand value exceeded the combined brand value of Microsoft's and IBM's individual brand values. Legendary Coca-Cola's iconic brand value slipped to $\# 3^{\text {rd }}$ rank with $\$ 78.4$ Billion in estimated brand value.

By closely collaborating with his chief designer Joni Ives, Steve Jobs turned the product innovation process at Apple on its head. Prior to his return, the engineers and manufacturers at Apple decided the functionality and the technical components needed to engineering design a product. There was limited consultations with their designers. Or the marketers came in with what they claimed 'their' customers must have. The designers were called in at the very end - primarily to skin the pre-determined components with a decorative veneer. Jobs turned the whole product innovation process on its head. Designers, with empathy for their users' experiences, prototyped and decided what a product or service should look and feel like. Then the engineers were told to pack in the functional components, and marketers were told to wait for the millions of delighted loyal customers come knocking on their doors - as they actually did sometimes waiting all night in lines under rain or holiday snow.

\section{Reviving design sensibility}

In 1985, CEO Steve Jobs was mostly edged out by the board of the company he co-founded and raised since April 1976 with Steve Wozniak and Mike Markkula (Isaacson, 2011). Under CEO John Sculley who was brought in from Pepsi by Jobs to make Apple more retail savvy, Apple struggled for a over a decade.

From 1993 to 1996, Apple switched CEOs three times, from John Sculley to Michael Spindler, and Gil Amelio. In 1995 Microsoft launched its very popular Windows 95, and a year later Apple's sales for Macintosh desk top computers crashed precipitously.

In 1997, Jobs partnered with his arch-rival Bill Gates at Microsoft and received an infusion of $\$ 150$ million that Apple badly needed (Isaacson, 2011). Microsoft was able to launch Microsoft Office for Macintosh - a blockbuster for both.

Jobs completely re-innovated Apple's desktop computer between 1998 and 2001, and launched it with a radical new design as iMac. It came in bright unprecedented colors such as purple, green, and blue. This revived the Apple brand significantly. To promote the corporate brand further, in May 2001 Apple announced the opening of Apple's iStores to directly educate and interface with their consumers. It cost money, the sales stayed low in $\$ 5$ Billion range, and the net income hit rock bottom hovering below $\$ 100$ Million. With all these shortages, Jobs kept funding R\&D by more than $\$ 400$ Million. (See Table-2). In October 2001, Apple innovated iPod digital audio player, which was seamlessly integrated with iMac, and legally downloadable iTunes - all visible and available to play in iStores. Jobs, thus took complete control of Apple's corporate brand, from end-to-end. All these rollouts cost money and took time to get the results in earnings. But gradually sales started running upwards.
Table-2: Apple’s Financials for selected turnaround years

\begin{tabular}{|c|c|c|c|c|c|}
\hline $\begin{array}{l}\text { YEAR } \\
\text { (\$Mil.) }\end{array}$ & $\begin{array}{l}\text { NET } \\
\text { SALES }\end{array}$ & $\begin{array}{l}\text { COST OF } \\
\text { SALES }\end{array}$ & $\begin{array}{l}\text { GROSS } \\
\text { MARGIN }\end{array}$ & $\mathrm{R} \& \mathrm{D}$ & $\begin{array}{c}\text { NET } \\
\text { INCOME }\end{array}$ \\
\hline 1996 & 9,833 & 8,865 & 968 & 604 & -816 \\
\hline 1997 & 7,081 & 5,713 & 1,368 & 485 & $-1,045$ \\
\hline 1998 & 5,941 & 4,462 & 1,479 & 303 & +309 \\
\hline 1999 & 6,134 & 4,438 & 1,696 & 314 & +601 \\
\hline 2000 & 7,983 & 5,817 & 2,166 & 380 & +786 \\
\hline 2001 & 5,363 & 4,128 & 1,235 & 430 & -25 \\
\hline 2002 & 5,742 & 4,139 & 1,603 & 446 & +65 \\
\hline 2003 & 6,207 & 4,499 & 1,708 & 471 & +69 \\
\hline 2004 & 8,279 & 6,020 & 2,259 & 489 & +276 \\
\hline 2005 & 13,931 & 9,888 & 4,043 & 534 & $+1,335$ \\
\hline 2006 & 19,315 & 13,717 & 5,598 & 712 & $+1,989$ \\
\hline 2008 & 32,479 & 21,334 & 11,145 & 1,109 & $+4,834$ \\
\hline 2009 & 36,537 & 23,397 & 13,140 & 1,133 & $+5,704$ \\
\hline 2010 & 65,225 & 39,541 & 25,684 & 1,782 & $+14,013$ \\
\hline 2011 & 108,249 & 64,431 & 43,818 & 2,429 & $+25,922$ \\
\hline 2012 & 156,508 & 87,846 & 68,662 & 3,381 & $+41,733$ \\
\hline 2013 & 171,910 & 106,606 & 64,304 & 4,475 & $+37,037$ \\
\hline
\end{tabular}

In 2004, as the financials perked up at Apple, so did its innovativeness and corporate brand value. In 2005, corporate brand value of Apple recovered by double digits to $\$ 8.0$ billion, and it ranked as \#41 on the Top 100 Most Valuable Global Brands (See Table-1).

With financial success and growing net income, under Steve Jobs Apple become even more innovative. He innovated products with dramatic technological capabilities such as iPod Video and iPod Touch, which delighted his customers. And, then in 2007 he radically disrupted the phone market with the launch of innovative rulebreaking and elegantly designed mobile iPhone. Between 2007 and 2013, Apple kept upgrading iPod and iPhone product lines. Apple's corporate brand value rose with its innovation capabilities.

\section{Case study 3: Corporate brand value of Samsung}

Since 2000, Japanese enterprises have been steadily losing their brand values of their coveted brands relative to their global rivals not only from the US, but also from South Korea. In global electronics industry, in 2000 Samsung's brand value of $\$ 5.2$ Billion was less than $1 / 3^{\text {rd }}$ of Sony's brand value \$16.4 Billion.

In just 15 years in 2015, Samsung's $\$ 45.3$ billion brand value had increased to approx. 7 times Sony's highly eroded $\$ 7.7$ Billion brand value, and more than 7 times Panasonic's \$6.4 Billion (See Table-1). In fact, Samsung's brand value was almost twice as much as the total brand value of Japan's top 3 brands Cannon, Sony, and Panasonic combined.

How did Samsung boost its corporate brand value so sky high, ahead of other consumer electronics makers? 
Charismatic leadership and design-driven transformation Until 1995, Samsung Electronics of South Korea manufactured imitative, inexpensive electronic parts and components for other originalequipment manufacturers (OEMs). They were made to make things according to the specifications and target costs mandated to them. The company's strategic leaders valued efficiency, scale, reliability, and speed - with low-cost leadership (Gehani, 2013).

In 1996, Samsung Group Chairman Lee Kun-Hee became quite visibly frustrated with Samsung's defective products and lack of innovation. He made a big public display of how frustrated he was by gathering thousands of defective phones produced by Samsung in the lobby of the corporate office. And then he ran a bulldozer over it (Khanna, Song \& Lee, 2011). He often smashed phones against the walls to check how rugged they were built. His recommendation to senior Samsung executives: test the phones by throwing them against the wall (Gehani, 2013).

Chairman Lee supported the new design training programs with his personal attention and a high priority. Nobody could derail them even during the 1997 financial economic downturn. The newly trained designers developed a holistic view. The designers used the same tools as the ones they used for innovation: empathy, visualization, and experimentation. They combined these to rapidly develop Samsung's dynamic technological capabilities.

\section{Outside-in \& inside-out open talent development}

Lee was acutely aware of need for world-class talent. To promote open innovation, he instituted a two-pronged global talent development program (Khanna et al., 2011). This involved sending Samsung managers with good mental capabilities to go abroad for 18-24 months. They learned the local languages, made contacts with some important local people, and completed an important value-adding innovation project. This was not unlike what Lee's predecessors had done by going to Japan to earn engineering degrees at some of the major Japanese universities like Tokyo Institute of Technology and Kyoto University.

The second prong of Lee's talent development program was Samsung recruiters going to the West and hiring the best Korean and nonKorean MBAs, engineers, and $\mathrm{PhDs}$ from leading companies and consulting firms in US and Europe (Khanna et al., 2011). They were then appointed in key positions. To facilitate their smooth entry in the Korean organizations, they were given extensive orientation and mentoring by senior Korean strategic leaders.

When Samsung Electronics branched out on its own from the conglomerate, it was in head-to-head in mortal combat with global electronics giants like Apple and Sony. In 2014Q3, Samsung's profit fell $60 \%$ year-to-year. In 2015Q1 it recovered a little, but it was still below the year before. In the face of world-wide popularity of iPhone, only Samsung survived. The phone divisions of former rivals such as Motorola, Nokia, Blackberry, and Ericsson are almost gone. Partly this is because since 2006, Samsung has retained its leadership in global TV market with its blockbuster brands like One Design, Curved Smart, Bordeaux and Touch of Color. Smartphone sales have also contributed to record earnings for Samsung (See Table-3).
Table-3: Samsung's Financials for selected turnaround years

\begin{tabular}{cccccc}
\hline $\begin{array}{c}\text { YEAR } \\
\text { (\$Mil) }\end{array}$ & $\begin{array}{c}\text { NET } \\
\text { SALES }\end{array}$ & $\begin{array}{c}\text { COST OF } \\
\text { SALES }\end{array}$ & $\begin{array}{c}\text { GROSS } \\
\text { MARGIN }\end{array}$ & R\&D & $\begin{array}{c}\text { NET } \\
\text { INCOME }\end{array}$ \\
\hline 2009 & 117,821 & 81,756 & 36,065 & 6,384 & 8,436 \\
2010 & 137,905 & 91,562 & 46,343 & 8,115 & 14,400 \\
2011 & 142,403 & 96,785 & 45,618 & 8,613 & 11,853 \\
2012 & 188,351 & 118,621 & 69,730 & n.a. & 22,333 \\
2013 & 217,462 & 130,934 & 86,528 & n.a. & 28,978 \\
\hline
\end{tabular}

So: Mergent Database.

\section{Innovating Galaxy Note}

Samsung has been constantly looking out for innovative entrepreneurial opportunities. After introducing Galaxy S smartphone and Galaxy Tab tablet, Samsung designers noted a market gap (Yoo \& Kim, 2015). Many Japanese and Korean workers have been traditionally carrying a small pocket diary to take notes during their meetings. Neither the 4 " screen phone, nor 9" screen tablet provided a good substitute for this pocket diary. Samsung realize that this would need a new technology platform. Samsung designers quickly developed a design concept for a smart diary with 5.5 " screen and a pen interface. When this design concept was pitched to Samsung's senior managers, they questioned the new screen size. The conventional thinking by their marketing department was that screens for mobile pocket phones can not be larger than 5". The critics objected that the phone users will not put such a big thing next to their face. It will make their face look smaller.

The new phone platform required changing users' attitude towards mobile phones. Samsung designers created a mock-up that looked like a diary for test marketing. It had a smart cover that did not make it look that big. The innovative new 'phalbet' category made Galaxy Note series very successful and profitable. Samsung uses its smart cover strategy for other products, such as smaller Galaxy S.

\section{Case study 4: Corporate brand value of Toyota}

In the global automobile industry, brand values of Toyota (and Honda) continue to dominate far ahead of the global brand values of the rest of automakers. Toyota's brand value of \$49.1 Billion in 2015 is more than double the brand value of Honda's brand value of $\$ 23.0$ Billion, and more than four times the brand value of Ford with longer heritage at $\$ 11.6$ Billion. Just over a decade earlier, at the dawn of the $21^{\text {st }}$ century in 2000 , the $\$ 36.4$ Billion brand value of Ford was almost twice as much as Toyota's $\$ 18.8$ Billion brand value. Toyota achieved this by ramping up its production process innovation much faster than Ford's and others.'

\section{Open innovation in collaboration with strategic suppliers}

Toyota's brand became one of the world's most valuable brands with its production process innovation, often known as lean production system. One of the key components of Toyota's innovation strategy is its collaborative open innovation with its suppliers (Iyer, Seshadri, \& Vasher, 2009). Compared to its American rivals, such as General Motors, Ford, and Chrysler, Toyota (as well as Honda) use a closeknit and integrated collaboration with its suppliers. 
Womack, Jones and Roos (1990) in their best-selling book The Machine That Changed the World, shared how Toyota's production process innovation disrupted the global auto industry in general, and the U.S. automakers in particular. Clark and Fujimoto (1991) identified the different stage operations and decision-making gates in the innovative lean product development process of Toyota. These observations have been validated by many other researchers (Gehani, 1992; Ulrich \& Eppinger, 2008).

There is generally a much higher level of mutual trust between Toyota and its suppliers (Iyer, Seshadri, \& Vasher, 2009). Many American auto corporations tend to swing between adversarial and collaborative open relationships with their suppliers. On the other hand, at Toyota there is much less contract-related paperwork and transactional cost than at Ford or GM. For example, Toyota has only a 16 page project requirement document with its major suppliers, whereas Toyota's North American rivals use 3.5 times longer 56 page project requirement document (Pereira, Ro and Liker, 2014: 547).

Toyota also uses a single-point of contact (a cross-trained engineer) for all communications with a supplier regarding a project's requirements. At rival American corporations, the project requirements are controlled by multiple persons in the purchasing department with different disciplinary backgrounds (Pereira, Ro and Liker, 2014). Toyota, invests much more in training and development of the competence of their engineers, but spends much less time coordinating with suppliers than do rival American auto makers.

\section{Enterprise culture}

Leaders at Toyota have often claimed that the most important secret to the success of their lean process innovation strategy is their culture (Takeuchi, Osono \& Shimizu, 2008). It codifies certain problem-solving practices that are etched deep into the hearts and souls of their people

Schein (1984) noted that culture within an organization is like a threelayered wedding cake. What we see at the surface are the culture's artifacts. These artifacts are built on a layer of stated values, and the shared beliefs make the bottom layer. Whereas U.S. automakers have spent decades trying to imitate or replicate some aspects of Toyota's enterprise culture, they have barely scratched some surface artifacts of Toyota's culture (Pereira, Ro and Liker, 2014). There is still a chasm of differences in values and beliefs. Some key differences are as follows:

1. Employee Engagement. More designers and engineers are actively engaged in Toyota than their counterparts in rival U.S. auto enterprises. Through life-long employment, job-rotation, and job-enrichment, Toyota continually builds the capabilities and competencies of its work-forces deep down into the trenches of production and operations.

2. Visual Communication. Toyota uses more visual communication and illustrations than the rival U.S. automakers. There is frequent face-to-face and digital technology mediated communication. The communication intensity increases when key decisions need to be made. On the other hand, the communication intensity at U.S. automakers increases when there is crisis which happens quite frequently. The Kanban just-in-time production system encourages widespread sharing and visual display of key information (Gehani, 2001).

3. Reduction of Variability Risks: Toyota reduces its variability risk by using clearly articulated specifications and by production of products with consistent quality. The U.S. rivals add to their risk when they use unclear specifications and frequently change their suppliers on case-by-case or minimum cost-basis.

4. Fact-based Decision Making. Most Japanese enterprises, including Toyota, use collective decision-making (nemawashi) to reduce their risk of making wrong decisions (Gehani, 2001). At Toyota most of the design decisions are based on concrete objective facts rather than subjective judgments by individual supervisors - particularly managers far removed from the gemba work-site. Whenever there are disagreements, Japanese employees at all levels are mandated to go back to the basic facts. In many U.S. enterprises, design decisions are often made somewhat arbitrarily by the people higher up in the hierarchy because of their more authoritative power. For example, on one hand, an executive may fire a few designers in the guise of cutting cost and improving the bottom line. But at the same time, or soon thereafter, additional supporting administrators may be hired at many times more salaries (because they worked with the executive during their former employment).

\section{Discussion}

\section{Lessons for corporate brand value from dynamic innovative capabilities}

What lessons can be learned from the evolutionary grounded theory accounts of these multiple case studies. From the foregoing observations from four of the most valuable global corporate brands, it is quite clear that to sustain their brand values, enterprises must cultivate their unique value-adding resources, and build their dynamic innovative capabilities to improve their competitive advantage (Gehani, 1998). We explicate these briefly below to show how the rules of competition have changed.

\section{Build dynamic capabilities}

The dynamics of competition, value capture, and value creation is now changing fast in most industries (Ryall, 2013). Some resources and capabilities are ordinary and commonplace - which every other rival corporation can quickly access too. Enterprises use these resources to run their hierarchical or entrepreneurial organizations. Their staff must be recruited, paid wages, trained, organized, and motivated to contribute at their fullest potential. Government regulations must be complied. The workplace must be safe and free of hazards. Suppliers must be selected, certified, and coordinated. Sales deals must be closed. Banks and other lenders must be paid back on time - or else they can shut the enterprise down according to the contract terms signed. These ordinary resources and capabilities are necessary to run any enterprise - but these are not sufficient to win the market race. They do not help gain sustainable competitive advantage. 
To beat the competition in the market space, on a sustained basis, especially in turbulent and complex global markets, such as for electronic appliances and automobiles, enterprises must develop their unique, idiosyncratic value-adding, and hard to imitate resources and capabilities. This is known as the resource-based view of competitive strategy (Wernerfelt, 1984; Barney, 1991).

And then in fast clock-speed evolving industries and global markets, such as the information technology industry or the smartphone industry, the strategic leaders must accept that the intensity of rivalry as well as the market entry rules of the competitive games may altogether change periodically every few years (Ryall, 2013, Christensen, 1997). This requires new strategies for innovation.

\section{Need for ongoing open innovations}

Even for the well-established corporate brands, such as Coca-Cola, Kodak, or General Motors, heritage is not enough. They must keep innovating as Coca-Cola is doing, and Kodak and GM did not. The strategic leaders at Eastman Kodak in the 1990s thought that they would be able to continue to leverage their 100-year old iconic brand and continue to earn fat profit margins - forever (Gamble and Gehani, 2013). At first the resolution and quality of 'disruptive' digital images was inferior, and it did not pose a significant threat to Kodak's high quality photographic films (Gehani, 1993). But Kodak's digital rivals kept getting more innovative, and Kodak stood still. Kodak's loyal customers left and the new generation of Millennial consumers did not see any sizzle in the Kodak brand. In January 2012 Kodak was forced to file for Chapter 11 bankruptcy protection (Gamble and Gehani, 2012). After taking care of bankruptcy protection requirements, Kodak must innovate hard, like Apple and Samsung, to recover its lost market ground. Only with innovation, Kodak can re-rise like a phoenix and recover back its legendary reputation and brand value.

\section{Appreciative culture}

As we saw in the case of Toyota's culture, strategic leaders can not overlook the creative and innovative power of their people's imagination and trust. Leading brand owners like Google and Microsoft tap that regularly. The challenge is how to unleash this sub-merged intellect and vitality after the top and middle managements have been ill-treating their operations staff with mistrust and abuse of rampant layoffs. Every time Kodak's leadership felt that the Kodak's stock was slipping too low, they laid off a few more thousand employees to please the short-term expectations of their Wall Street shareholders (Gamble and Gehani, 2012). This sometimes temporarily increased their gross profitability (sales per employee), but very often Kodak paid the price with their employees' falling morale and long-term productivity. Many U.S. companies tend to do this under pressure from their aggressive short-term shareholders. Leaders must reverse years of such autocratic abuses. Only then employees will wholeheartedly follow their leaders and contribute their imagination and innovativeness. As noted before, the underlying beliefs and ingrained attitudes drive the employees' behavior and the corporation's culture.

The personality of an organization's culture also drives the corporate brand value (Aaker, 2004: 8). Credible leaders such as Tim Cook at Apple, Bill Gates at Microsoft, and Charles Bronson at Virgin Atlantic, can sway their thousands of followers distributed around the world into action. Such leaders use their own deeds as well as words to inspire others. Other leaders must earn such employee and customer following.

\section{Perceived innovative}

Almost all enterprises and their strategic leaders, including owners of falling brands such as General Motors, Chrysler, or Sharp, prefer to believe that they are innovative - and believe that they are perceived as innovative by their employees and customers. Whereas some employees may be forced to believe this for short periods of time, some of the employees and most of the savvy customers can make a quick comparison with their rivals' offerings. With Internet and social media, it has become easy to see through the veneer of purchased promotional haze. Unfortunately, many top management leaders, surround themselves with their supporters, and start believing their own hype. It is not hard for tire users around the world to compare tires offered by global brand rivals Goodyear, Bridgestone, and Michelin. Same is the case with smart phones, tablet computers, and automobiles. Every brand owner can spend money to buy media time, and claim great things. A key factor that many knowledgeable customers look for is whether a brand actually delivers on its brand promises.

Perceived quality and perceived innovation, sometimes, may be harder to achieve than delivering actual quality and actual innovation (Aaker, 2004: 8). Every small cue counts in building up the perception, trust, and reputation behind a brand.

\section{Design thinking and user empathy}

Finally, as we noted earlier, empathy with users' experiences, resonance with their emotions, and honoring customers' sensory perceptions are the new killer apps that design-driven innovative corporate brand leaders, like Apple, Google, and Samsung and others, frequently use. To facilitate this, Samsung's design teams hired artists, writers, and ethnographers. Coca-Cola has been doing this successfully for 130 years. Steve Jobs did this intuitively rather than through market research. If Toyota did this more, there would be less recalls.

Design thinking also promotes frequent risk-taking and prototyping. When Steve Jobs returned to Apple in September 1997, Apple was within weeks of filing for bankruptcy. He shut down many incremental improvements, and focused on a few bold and breakthrough innovations such as iPod, iTunes, and iPhone. This paid off enormous returns in profitability and brand value, for many years come. More Japanese brand owners like Sony, Sharp, Toshiba, and Nissan could emulate such bold risk-taking. It is now possible to innovate on the run.

\section{Conclusion}

In conclusion, most practicing managers around the world must recognize that corporate brand value is one of the most important strategic asset that they must manage. This paper, therefore, set out 
with a big challenge to re-examine the age-old tradition of building corporate brand values based on corporate identity, legacy, and stakeholder interactions. We did this by using a more appropriate research method of grounded theory approach coupled with case studies, and quantitative and qualitative data. Our evolutionary studies indicated that in the $21^{\text {st }}$ Century, the corporate brand values are more closely correlated with the firms' dynamic innovative capability rather than their legacy or identity. We noted this in the case of the fall of the iconic brands of Eastman Kodak and General Motors, and we saw this in the phenomenal rise of corporate brand values of Apple and upstart Samsung. Legendary Coca-Cola keeps up its brand value with close connectivity with their customers and other shareholders such as women and environmentalists. Toyota does this through its reliable products coupled with an enigmatic and paradoxical corporate culture.

Future research studies, could explore these seminal findings for larger number of brands, and cull out the moderating influences of size of the firm, industry type, age or legacy, product features etc.. Another interesting line of inquiry will be to research the effect of cross-cultural and national differences. Corporate brand value has now become so critical that no managers and researchers can ignore it. Hopefully, this study paved the way for many more researchers to follow and more managers to practice.

\section{References:}

Aaker, D. A. (1991). Managing Brand Equity. New York: The Free Press.

Aaker, D. A. (2004). Leveraging the Corporate Brand. California Management Review, 46(3, Spring): 6-18.

Aaker, D. A. (2012). Win the Brand Relevance Battle and then Build Competitor Barriers. California Management Review, 54 (2, Winter): 43-57.

Abratt, R. \& Kleyn, N. (2012). Corporate Identity, Corporate Branding and Corporate Traditions, Reconciliation and Integration. European Journal of Marketing, 46(7/8): 1048-1063.

Acevedo, J. (2008). Happiness in a Bottle. Brand Packaging, Oct./Nov.: 2.

Ambler, T. and Styles, C. (1997). Brand Development Versus New Product Development: Toward a Process Model of Extension Decisions. Journal of Product and Brand Management, 6(4): 222-234.

American marketing Association. (1960). Marketing Definitions: A Glossary of Marketing Terms. Chicago, IL: AMA.

Balmer, J. M. T. (2012). Strategic Corporate Brand Alignment: Perspectives From Identity Based Views of Corporate Brands. European Journal of Marketing, 46(7/8): 1064-1092.

Barney, J.B. (1991). Firm resources and sustained competitive advantage. Journal of Management, 17: 99-120.
Christensen, C. M. (1997). Making Strategy: Learning By Doing. Harvard Business Review, Nov.-Dec.: 141-156.

Christensen, K. (2013). Inside Coca-Cola: The Evolution of an Iconic Brand. Rotman Management, Fall: 64-67.

Clark, K. and Fujimoto, T. (1991). Product Development Performance: Strategy, Organization, and Management in the World Auto Industry. Boston, MA: Harvard Business School Press.

Daneman, M. (2014, Dec. 16). Kodak's Bankruptcy is Finally Done. Democrat \& Chronicle, p1.

Eisenhardt, K. \& Graebner, M. (2007). Theory Building From Cases: Opportunities and Challenges. Academy Management. Journal, 50(1): 25-32.

Elliott, S. (2013, Sept. 30). Apple Passes Coca-Cola a Most Valuable Brand. The New York Times, pB5.

Gallagher, M. (2014). Integrating design with engineering: Mike Gallagher. Research-Technology Management May-Jun: 64.

Gehani, R. R. (1992). Concurrent product development for fast-track corporations. Long Range Planning, 25(6, Nov.-Dec.): 40-47.

Gehani, R. R. (1993). Quality value-chain: A meta-synthesis of frontiers of quality. Academy Of Management Executive, 7(2, May): 29-42.

Gehani, R. R. (1995). Time based management of technology. International Journal of Operations and Production Management, 15(2, April): 19-35.

Gehani, R. R. (1998). Management of Technology \& Operations. New York: John Wiley \& Sons.

Gehani, R. R. (2001). Revisiting 'The False Promise of The Japanese Miracle' for Discontinuous Innovation Under Economic Stagnation. Global Focus, 13(2): 197-212.

Gehani, R. R. (2013). Strategic leader transforming from a low-cost strategy to product differentiation strategy. Journal of Technology Management and Innovation, 8(2): 144-155.

Glaser, B. and Strauss, A. (1967). The Discovery of Grounded Theory: Strategies for Qualitative Research. London, U.K.: Aldine.

Isaacson, W. (2011). Steve Jobs. New York: Simon \& Schuster.

Isidore, C. (2009, June 2). GM Bankruptcy: End of an Era. CNNMoney.com.

Interbrand Global Brand Value Rankings. www.interbrand.com. Various Annual listings (2000-2015). Downloaded January 21, 2016.

Iyer, A. V.,' Seshadri, S., and Vasher, R. (2009). Toyota Supply Chain Management: A Strategic Approach to the Principles of Toyota's Renowned System. New York: McGraw-Hill. 
Kapferer, J.N. (1997). $2^{\text {nd }}$ Ed. Strategic Brand Management. London: Kogan Page.

Keller, K.L. (1998). Building, Measuring, and Managing Brand Equity, Englewood, NJ: Prentice Hall.

Khanna, T., Song, J., and Lee, K. (2011). The Paradox of Samsung's Rise. Harvard Business Review, Jul.-Aug.: 1-7.

Melewar, T. C. Gotsi, M. and Andriopoulos, C. (2012). Shaping the Research Agenda for Corporate Branding: Avenues for Future Research. European Journal of Marketing, 46(5): 600-608.

Overbolt, A. (2012). Business + Innovation. Fast Company, June: 5.

Pereira, R., Ro, Y. K. \& Liker, J. K. (2014). Product Development and Failures in Learning From Best Practices in U.S. Auto: A Supplier Perspective. IEEE Transactions on Engineering Management, 61(3 Aug.): 545-556.

Perrow, C. (1967). A Framework for the Comparative Analysis of Organizations. American Sociological Review, 32(2): 194-208.

Porter, M. E. \& Happelmann, J. E. (2014). How Smart Connected Products are Transforming Competition, Harvard Business Review, Nov.: 65-88.

Schein, E. (1984). Coming to a new awareness of organizational culture. Sloan Management Review, 25(2): 3-16.

Srivastava, R.K. and Shocker, A.D. (1991). Brand Equity: A Perspective on Its Meaning and Measurement. Working Paper. Marketing
Science Institute. Boston, MA.

Takeuchi, H., Osono, E. \& Shimizu, N. (2008). The Contradictions That Drive Toyota's Success. Harvard Business Review, June: 1-8.

Ryall, M. D. (2013). The New Dynamics of Competition. Harvard Business Review, June: 80-87.

Ulrich, K. and Eppinger, S. (2008). Product Design and Development. New York: McGraw-Hill.

Wernerfelt, R. (1984). A resource-based view of the firm. Strategic Management Journal 5: 171-180.

Womack, J., Jones, D. \& Roos, D. (1990). The Machine That Changed the

World. New York: Rawson Associates.

Wood, L. (2000). Brands and Brand Equity: Definition and Management. Management Decision, 38:9. P: n.a.

Wright, L. T., Millman, C., and Martin, L. M. (2007). Research Issues in Building Brand Equity and Global Brands in the PC Market. Journal of Marketing Management. 23(1/2): 137-155.

Yin, R. (1994). Case Study Research: Design \& Methods. Thousand Oaks, CA: Sage.

Yoo, Y. \& Kim, K. (2015). How Samsung Became a Design Powerhouse. Harvard Business Review, Sept.: 73-78. 